AMERICAN JOURNAL BIOTECHNOLOGY AND MOLECULAR SCIENCES

ISSN Print: 2159-3698, ISSN Online: 2159-3701, doi:10.5251/ajbms.2012.2.1.1.5

(C) 2012, ScienceHu $\beta$, http://www.scihub.org/AJBMS

\title{
In vitro antimicrobial evaluation of Kaempferia galanga L. rhizome extract
}

\author{
Kochuthressia K. P. ${ }^{1}$ S.John Britto ${ }^{2}$, Jaseentha M.O' and Rini Raphael ${ }^{3}$ \\ ${ }^{1}$ Dept of Botany , Carmel College, Mala, Trissur-680732 \\ ${ }^{2}$ The Rapinat Herbarium and Centre for Molecular Systematics \\ St.Joseph's College (Autonomous), Tiruchirappalli-620 002 \\ ${ }^{3}$ Dept of Zoology, Carmel College, Mala, Trissur-680732
}

\begin{abstract}
In the present study, antimicrobial activity of ethanol, methanol, petroleum ether, chloroform and aqueous extracts of Kaempferia galanga rhizome were screened aganist ten human pathogenic bacteria such as Staphylococcus aureus, Streptococcus faecalis, Bacillus cereus, Bacillus subtilis, Enterobacter aerogenes, Salmonella typhi, Escherichia coli, Klebsiella pneumoniae, Pesudomonas aeruginosa and Vibrio cholerae and four fungal species :Aspergillus niger, $A$. flavus, A.fumigatus and Candida albicans susing disc diffusion assay. All the extracts showed significant antibacterial and antifungal properties. Highest inhibition zone (21.3 \pm 0.08$)$ was recorded for ethanolic extract against Staphylococcus aureus.
\end{abstract}

Key words : Rhizome, Kaempferia galanga, antimicrobial activity, disc diffusion assay.

\section{INTRODUCTION}

Herbal medicines are gaining priorities in treating various health ailments of diverse origins in man. Before the inventions of the modern synthetic medicines, man's dependence was totally on plants. Traditional systems of plant based products have existed with the changes in culture, traditions and mode of life of man; except for a short period when the inventions of the modern synthetic medicines came into existence. Plant based antimicrobials have enormous therapeutical potential as they can serve the purpose without any side effects that are often associated with synthetic antimicrobials. Continued exploration of plant derived antimicrobials is needed today (Hussain et al., 2004).The pathogenic microorganisms can be controlled with the antibiotics presently available; however the need of new antibiotics has increased due to current problems of resistance associated with them (Davies, 1994 and Prabhat et al., 2005). The drug resistant bacteria and fungal pathogens have complicated the treatment of infectious diseases. In the present scenario of emergence of multiple drug resistance to human pathogenic organisms this has necessitated a search for new antimicrobial substances from other sources including plants. Traditionally used medicinal plants produce a variety of compounds of known therapeutic properties (Harbone and Baxter, 1995). The substances that can either inhibit the growth of pathogen or kill them and have no or least toxicity to host cells are considered candidates for developing new antimicrobial drugs. The antimicrobial properties of medicinal plants are being increasingly reported from different parts of the world (Saxena, 1999). It is expected that plant extracts showing target sites other than those used by antibiotics will be active against drug resistant microbial pathogen

Kaempferia galanga $\mathrm{L}$. is one of the valuable medicinal plants in Zingiberaceae family, an aromatic rhizomatous herbal spice, is an ingredient of many aurvedic drug preparations (Sadimann 1992). The rhizome and root tubers are used for curing bronchitis, asthma, malaria, skin disease, wounds and spleenic disorders (Kirtikar \& Basu 1997). The ethyl p-methoxy transcinnamate present in the rhizome extract is highly cytotoxic to $\mathrm{He} \mathrm{La}$ cells (Kosuge et al., 1985). Larvicidal and anticancer principles have also been reported from the rhizome extracts (Kiuchi et al., 1988, Kosuge et al., 1985). Rhizome extract contain n-pentadecane, ethyl pmethoxy cinnamate, ethyl cinnamate, I- $\Delta 3$ carene, camphene, berneol, cineol, p- methoxy styrene, kaempferol, kaempferide (Anonymous, 1959). Leaves and flowers contain flavanoids (Ghani 1998). The 95\% ethanol extract of this plant possessed antibacterial activity against Staphylococcus aureus and hot water extract against Escherichia coli (George and Pandalai, 1949). Recently, Arambewela et al (1999) reported that the essential oils of $K$. galanga root and rhizome showed antibacterial activity against Escherichia coli and Staphylococcus aureus. Parvez et al., 2005 reported that the petroleum ether and methanol extract of $K$. galanga showed significant activity against Gram positive and 
Gram negative bacteria. The present study was undertaken to determine the antibacterial and antifungal sensitivity of the Kaempferia galanga rhizome extracts.

\section{MATERIALS AND METHODS}

Plant sources: Kaempferia galanga plants were collected from Kerala Agriculture University, Vellanikkara, Trissur, Kerala. They were identified at the Rapinat Herbarium, St. Josephs college (Autonomous) Tiruchirapalli, S. india and a voucher specimen was also deposited.

Extract preparation: $50 \mathrm{gms}$ of shade dried powdered materials of rhizome were soaked in $300 \mathrm{ml}$ of each of the solvent viz ethanol, methanol, petoleum ether, chloroform and aqueous in a soxhlet apparutus for 72 hour at $31^{\circ} \mathrm{C}$ until complete exhaustion of the material .Each mixture was stirred at every 24 hour using a sterile glass rod. At the end of 72 hour each extract was passed through whatmann No.1 filter paper and filtrates were concentrated in vaccum rotary evaporator in order to reduce the volume into $50 \mathrm{ml}$. The extracts were stored in labelled screw bottles and kept in refrigerator at $4^{\circ} \mathrm{C}$.

Microbial strains and Culture media: Ten bacterial species: Staphylococcus aureus MTCC \# 3163, Streptococcus faecalis MTCC\# 459, Bacillus cereus MTCC \# 1306, Bacillus subtilis MTCC \# 121, Enterobacter aerogenes MTCC \# 2990, Salmonella typhi MTCC \#734, Escherichia coli MTCC \# 119 , Klebsiella pneumoniae MTCC \#3040,Pesudomonas aeruginosa MTCC \#2474 and Vibrio cholera. The fungal strains : Aspergillus niger MTCC \# 2612, A. flavus MTCC \# 2813, A. fumigatus MTCC \# 2584 and Candida albicans MTCC \# 1637 were used for this study. Bacterial stock cultures were subcultured in nutrient broth for incubation at $37^{\circ} \mathrm{C}$. The $24 \mathrm{hr}$ culture was stirred with $0.9 \%$ saline to achieve $0.5 \mathrm{Mc}$ farland (10 $8 \mathrm{cells} / \mathrm{ml}$ for bacteria and $10^{6}$ for fungi) (Okusa et al., 2007). Kannamycin and nystatin were used as reference antibiotics (RA).

\section{Antimicrobial assay:}

Disc diffusion assay: The discs of $6 \mathrm{~mm}$ were prepared using a whatmann filter paper. 100 discs were obtained by punching and putting in vials bottles and sterilizing in an oven at $1500 \mathrm{C}$ for 15 minutes. The discs were impregnated with $10 \mu \mathrm{l}$ of concentrated crude extracts. The discs were evaporated at $37^{\circ} \mathrm{C}$ for $24 \mathrm{hr}$. Prepared discs containing the various fractions were carefully placed on the inoculated plates using a sterilized forceps in each case (Fatope and Adoum, 1993). The disc with solvent alone with which the extraction was carried out was used as negative control. The plates were then turned upside down and incubated at $37^{\circ} \mathrm{C}$ for $24 \mathrm{hr}$ in an incubator. The results were taken by considering the zone of growth and inhibition of the organism by the test fractions. Antimicrobial activity was evaluated by measuring the diameter of the inhibition zone (IZ) around the disc. The assay was repeated thrice and mean \pm SD was calculated (Kuete et al., 2007).

\section{RESULTS AND DISCUSSION}

Anitbacterial activity: The antibacterial activity of ethanol, methanol, petroleum ether, chloroform and aqueous extracts of Kaempferia galanga rhizome is presented in Table 1. The rhizome ethanolic extract showed higher degree of inhibition zone in Staphylococcus aureus $(21.3 \pm 0.08 \mathrm{~mm})$, Streptococcus faecalis (19.7 $\pm 0.37 \mathrm{~mm})$, Bacillus subtilis $(19.7 \pm 0.20 \mathrm{~mm})$ and $B$. cereus $(18.4 \pm 0.41$ $\mathrm{mm})$. The moderate inhibition was noted against Escherichia coli $(17.8 \pm 0.55 \mathrm{~mm})$ and Enterobacter aerogens $(16.2 \pm 0.37 \mathrm{~mm})$. The other bacteria showed inhibition zone such as Salmonella typhi $(15.5 \pm 0.17 \mathrm{~mm})$, Klebsiella pneumoniae $(14.9 \pm 0.95$ $\mathrm{mm})$, Vibrio cholerae $(12.3 \pm 0.16 \mathrm{~mm})$ and Pseudomonas aeruginosa $(12.1 \pm 0.40 \mathrm{~mm})$. This observation is in agreement with the report of earlier workers Sathish Kumar (2008) and Bualeea (2007), who reported that the ethanol extract produced strong inhibitory activities against some of the microorganisms. The methanol extract showed good activity in gram-positive bacteria such as $S$. aureus $(18.1 \pm 0.30 \mathrm{~mm})$ and $S$. faecalis $(16.4 \pm 0.34 \mathrm{~mm})$ and the gram-negative organism $E$. aerogenes $(15.6 \pm 0.26$ $\mathrm{mm}$ and Escherichia coli $(12.8 \pm 0.34 \mathrm{~mm})$. These research findings give a scope to further screen the chemical constituents of the extracts which will be very useful to compact the common infections caused by Staphylococcus aureus (Oonmetta-aree et al., 2006). The petroleum ether and chloroform rhizome extract showed higher level of inhibition zone in $B$. cereus $14.3 \pm 0.29 \mathrm{~mm}$ and $14.5 \pm 0.32 \mathrm{~mm}$ respectively. These results are also in substantial agreement with many previous studies (Burt, 2004; Maillard, 
Table 1. Antibacterial activity of rhizome extract of Kaempferia galanga - Disc diffusion method

\begin{tabular}{|c|c|c|c|c|c|c|}
\hline Microorganisms & $\begin{array}{c}\text { Ethanol } \\
\text { extract } \\
5 \mathrm{mg} / \text { disc }\end{array}$ & $\begin{array}{c}\text { Methanol } \\
\text { extract } \\
5 \mathrm{mg} / \text { disc } \\
\end{array}$ & $\begin{array}{c}\text { Petroleum ether } \\
\text { extract } \\
5 \mathrm{mg} / \text { disc } \\
\end{array}$ & $\begin{array}{c}\text { Chloroform } \\
\text { extract } \\
5 \mathrm{mg} / \mathrm{disc} \\
\end{array}$ & $\begin{array}{l}\text { Aqueous } \\
\text { extract } \\
5 \mathrm{mg} / \text { disc }\end{array}$ & $\begin{array}{l}\text { Standard } \\
\text { antibiotic } \\
30 \mu g / \text { disc }\end{array}$ \\
\hline Bacteria & \multicolumn{6}{|c|}{ Diameter of inhibition zone in $\mathrm{mm}$ (mean) } \\
\hline Staphylococcus aureus & $21.3 \pm 0.08$ & $18.1 \pm 0.30$ & $12.3 \pm 0.36$ & $10.4 \pm 0.25$ & $9.2 \pm 0.91$ & 23 \\
\hline Streptococcus faecalis & $19.7 \pm 0.37$ & $16.4 \pm 0.34$ & $13.4 \pm 0.62$ & $11.1 \pm 0.20$ & $10.1 \pm 0.29$ & 22 \\
\hline Bacillus cereus & $18.4 \pm 0.41$ & $14.2 \pm 0.13$ & $14.3 \pm 0.29$ & $14.5 \pm 0.32$ & $9.3 \pm 0.26$ & 23 \\
\hline Bacillus subtilis & $19.7 \pm 0.20$ & $15.1 \pm 0.57$ & $11.3 \pm 1.12$ & $12.6 \pm 0.26$ & $10.3 \pm 0.25$ & 20 \\
\hline Enterobacter aerogenes & $16.2 \pm 0.37$ & $15.6 \pm 0.26$ & $10.9 \pm 0.67$ & $10.8 \pm 0.46$ & $9.5 \pm 1.20$ & 20 \\
\hline Klebsiella pneumoniae & $14.9 \pm 0.95$ & $12.3 \pm 0.30$ & $10.1 \pm 0.24$ & $9.2 .1 \pm 0.92$ & $9.3 \pm 0.5$ & 25 \\
\hline Salmonella typhi & $15.5 \pm 0.17$ & $11.4 \pm 0.50$ & $12.7 \pm 0.23$ & $10.7 \pm 0.56$ & $8.8 \pm 1.39$ & 20 \\
\hline Escherichia coli & $17.8 \pm 0.55$ & $12.8 \pm 0.34$ & $12.4 \pm 0.25$ & $10.4 \pm 0.98$ & $8.2 \pm 0.92$ & 20 \\
\hline Pseudomonas aeruginosa & $12.1 \pm 0.40$ & $12.4 \pm 0.40$ & $9.3 \pm 0.49$ & $9.2 \pm 0.19$ & $8.9 \pm 1.30$ & 23 \\
\hline Vibrio cholerae & $12.3 \pm 0.16$ & $12.4 \pm 0.05$ & $9.3 \pm 0.25$ & $8.2 \pm 1.30$ & $8.2 \pm 1.30$ & 24 \\
\hline \multicolumn{7}{|c|}{ Mean of three replicate determination $\pm S \mathrm{D}$; } \\
\hline
\end{tabular}

Table 2. Antifungal activity of rhizome extract of Kaempferia galanga -disc diffusion method

\begin{tabular}{|c|c|c|c|c|c|c|}
\hline Microorganisms & $\begin{array}{c}\text { Ethanol } \\
\text { extract } 5 \mathrm{mg} / \text { disc }\end{array}$ & $\begin{array}{l}\text { Methanol } \\
\text { extract } \\
5 \mathrm{mg} / \text { disc }\end{array}$ & $\begin{array}{c}\text { Petroleum ether } \\
\text { extract } \\
5 \mathrm{mg} / \text { disc }\end{array}$ & $\begin{array}{c}\text { Chloroform extract } \\
5 \mathrm{mg} / \mathrm{disc}\end{array}$ & $\begin{array}{l}\text { Aqueous } \\
\text { extract } \\
5 \mathrm{mg} / \text { disc }\end{array}$ & $\begin{array}{l}\text { Standard } \\
\text { antibiotic } \\
30 \mu g / d i s c\end{array}$ \\
\hline Fungus & \multicolumn{6}{|c|}{ Diameter of inhibition zone in mm (mean) } \\
\hline Aspergillus niger & $16.3 \pm 0.45$ & $14.2 \pm 0.26$ & $12.4 \pm 0.39$ & $11.5 \pm 0.38$ & $9.3 \pm 0.27$ & 24 \\
\hline Aspergillus flavus & $15.3 \pm 0.36$ & $13.2 \pm 1.20$ & $11.4 \pm 0.21$ & $9.24 \pm 0.91$ & $9.2 \pm 1.10$ & 23 \\
\hline Aspergillus fumigatus & $14.0 \pm 0.48$ & $10.8 \pm 1.89$ & $10.3 \pm 0.46$ & $9.6 \pm 1.29$ & $9.2 \pm 1.5$ & 25 \\
\hline Candida albicans & $12.2 \pm 0.45$ & $11.3 \pm 1.39$ & $9.7 \pm 0.39$ & $9.5 \pm 0.49$ & $8.3 \pm 0.28$ & 24 \\
\hline
\end{tabular}


Antifungal activity: Rhizome ethanol extract showed maximum inhibition in Aspergillus niger $(16.4 \pm 0.45 \mathrm{~mm})$, A. flavus (15.3 \pm 0.36$)$, A. fumigatus $(14.0 \pm 0.48)$ and Candida albicans $(12.2 \pm 0.45 \mathrm{~mm})$. Methanolic rhizome extract showed high inhibition zone against Aspergillus niger (14.2 $\pm 0.26 \mathrm{~mm})$. Petroleum ether, chloroform and aqueous extracts exhibited moderate level of inhibition zone against all tested fungi (Table 2.). This observation is in agreement with the report of earlier workers Sathish Kumar (2008) and Bualeea (2007), who reported that the ethanol extract produced strong inhibitory activities against some of the microorganisms.

The antibacterial activity of plant extracts was not only due to one main active chemical but to the combined action of additional other compounds (Sunayana, 2003). Examples include Phenolic acids (Fernandez et al., 1996), alkaloids (Vanbeek et al., 1985, Chakraborty and Brantner, 1999),flavanoids, (Watcher et al., 1999), terpenes (Coveney et al., 1985), terpenoids (Habibi et al., 2000) and napthoquinones (Cai et al., 2000). It is clear that the chemical structure of the antimicrobial agents found in higher plants belong to most commonly encountered classes of higher plant secondary metabolites.

In conclusion K.galanga showed good in vitro antibacterial and antifungal effects. The result presented here may explain the traditional use of this plant.

\section{REFERENCES}

Anonymous (1959). The wealth of India. Vol V. (CSIR. New Delhi): pp 314.

Arambewela, L.S.R., Perera, A. and Wijesundera R.L.C. (1999). Antibacterial activity of Kaempferia galanga. Fitoterapia. 70 (4): 425-427.

Bualeea, C., Anan Ounaroonb and Rattima Jeenapongsa. (2007). Antidiabetic and Long-term Effects of Elaeocarpus grandiflorus. Muang, Phitsanulok. J. Pharma. Sci. 15 (1): 17-28.

Burt, S. (2004). Essential oils: Their antibacterial properties and potentiall applications in foods- a review. International Journal of Food Microbiology. 94: 223-253.

Cai,L., Wei, G.X., Vander Biji, P. and Wu, C.D. (2000). Namibian chewing stick Diospyros lyciodes, contains antibacterial compounds against oral pathogens. J. Agric food Chem. 48:909-914.

Chakraborty, A. and Brantner, A.H.(1999). Antibacterial steroid alkaloids from the stem bark of Holarrbena pubescens. J. Ethnopharmacol. 68:334-339.
Coveney, D., Fukuda, N., O' Reilly, J., Polonsky, J., Prange, T., Donnelly, D. M.X. and Abc, F. (1985). Antibacterial sesquiterpene aryl esters from armillaria mellea. J. Natural Product . 48: 10- 11.

Davies, J. (1994). Inactivation of antibiotic and the dissemination of resistance genes. Curr. Sci. 264: 375382.

Fernandes, M.A., Garcia, M. D. and Saens, M.T. (1986). Antibacterial activity of the phenolic acids fractions of Scrophularia frutescens and Scrophularia sambucifolla. J.Ethnopharmacol. 53: 11-14.

Fatope, M.O. And Adoum, O.A.(1993) . Bioactivity of some savanna plants in the brine shrimp lethality test and invitro anti- micrbial . Int. J. phamacog. 35(5): 334-337.

George, M. and Pandalai, K.M. (1949). Investigations on plant antibiotics part IV . Further search for antibiotic in Indian medicinal plants. Indian J. Med. Res. 37: 169181.

Ghani, A. (1998). Medicinal plants of Bangladesh: Chemical constitutions and use. Asiatic Soc. Bangladesh. Pp. 290-291.

Habibi, Z., Eftekhar, F., Sameiee, K. and Rustaiyan, A. (2000). Structure and antibacterial activity of six new labdane diterpeoid from Salvia leriaefolia. J.Natural Products. 63: 270-271.

Harborne, S.B. and Baxter, H. (1995). Phytochemical Dictionary. A Handbook of Bioactive Compounds from plants. Taylor and Francis, London.

Hussain, M.A. and Gorsi, M.S. (2004). Antibacterial activity of Nerium oleander Linn. Asia. J. Plant Sci. 3 (2): 177180.

Kirtikar, K.R. and Basu, B.D. (1997). Indian Medicinal Plants, Vol. VI. Bishen Singh Mahendra Pal Singh, Dehradun, India.

Kiuchi, F., Nakamura, N. and Tsuda, Y., Kondo, K., and Yoshimura, H. (1988). Studies on crude drugs effective on visceral larva migransll larvicidal principles in Kaempferia rhizome. Chem. Pharm. Bull. 36(1): 412415.

Kosuge, T., Yokca, M., Sugiyama, k., Saito, M., Iwata, Y., Makkura, M., Yamamoto, t., (1985). Studies on anticancer principles in Biota orientalis and Kaempferia galanga. Chem. Pharm. Bul. 33, 5565-5567.

Kuete, V., Nguemeving, J.R., Penlap Beng, V., Azebaze, A.G.B., Etoa, F.-X., Meyer, M., Bodo, B. and Nkengfack, A.E. (2007). Antimicrobial activity of the methanolic extracts and compounds from Vismia laurentii DeWild. (Guttiferae). J. Ethno-pharmacology. 109: 372-379.

Maillard, J. Y. (2002). Bacterial target sites for biocide action. Journal of Applied Microbiology Symposium Supplement. 92: 16S- 27S. 
Okusa, P. N., Penge o., devleeschower, M. and Duez, P.(2007). Direct and indirect antimicrobial effects and antioxidant activity of cordia gilletii de wild (Boraginaceae). Journal of Ethno-pharmacology. 112: 476-481.

Oonmetta-area, J., Suzukibb, T., Gasaluka, P. and Eumkeb, G. (2006). Antimicrobial properties and action of galangal (Alpinia galanga Linn.) on Staphylococcus aureus. LWT Food Sci. Tech. 39 (10): 1214-1220.

Prabhat, Navneet and ShriKrishna. (2005). Antibacterial activity of Mimusops elengi Bak. J. Environ. Conserv. 6 (2): $59-61$

Sathish Kumar, T., Shanmugam, S., Palvannan T. and Bharathi Kumara, V.M. (2008). Evaluation of Antioxidant Properties of Elaeocarpus ganitrus Roxb. leaves. Iran. J. Pharma. Res. 7 (3): 211-215.

Sadimann, J. 1992 Alittle known Asian Spice and medicinal plant (Kaempferia galanga L.). Pharmazie . 47: 636639.

Saxena, V.K. and Sharma, R.N. (1999). Antimicrobial activity of essential oil of Lantana aculeata. Fitoterapia. 70 (1): 59-60.

Sunayana, V., Vadivukkarasi, p., Rajendran. ., Francis Xavier. T. And Natarajan, E. (2003). Antibacterial potential of Plectranthus amboinicus (Lour). Spreng: A study in vitro. J. Swamy Bot. Club. 20; 55-58.

Vanbeek, T. A., Verpoorte, R. Svendsen, A.B. (1985). Antimicrobially active alkaloids from Tahemeemontana chippi. Journal of Natural Products. 48: 400-423.

Watchter, G.A., Hofmann, J., Furbacher, T., Blake, M.E. and Timmerman, B. N. (1999). Antibacterial and antifungal flavanones from Eysenhardtia texana. Phytochemistry. 52:1469-1471. 